\title{
Civilisations
}

Revue internationale d'anthropologie et de sciences

humaines

$63 \mid 2014$

L'Ancestralité revisitée

\section{From Worshipping Ancestors to Respecting Senior Citizens}

\section{Michael Singleton}

\section{OpenEdition \\ Journals}

Electronic version

URL: http://journals.openedition.org/civilisations/3771

DOI: 10.4000/civilisations.3771

ISSN: 2032-0442

\section{Publisher}

Institut de sociologie de l'Université Libre de Bruxelles

\section{Printed version}

Date of publication: 30 September 2014

Number of pages: 237-254

ISSN: 0009-8140

\section{Electronic reference}

Michael Singleton, «From Worshipping Ancestors to Respecting Senior Citizens », Civilisations [Online], 63 | 2014, Online since 30 September 2018, connection on 01 May 2019. URL : http:// journals.openedition.org/civilisations/3771 ; DOI : 10.4000/civilisations.3771

\section{(C) Tous droits réservés}




\title{
From Worshipping Ancestors to Respecting Senior Citizens
}

\author{
Michael SINGLETON
}

Summary: (Re)presenting the ethnographic evidence (as missionaries and anthropologists have tended to do) in terms of "ancestor worship" and consequently as a form of (primitive) religion could be yet another example of an excessively ethnocentric interpretation of what, in this instance and from a purely phenomenological point of view, plausibly amounts to nothing much more than the ceremonious recognition of the indispensable role senior citizens played in the survival of pre-modern rural communities. Redefining religion as "obligatory but asymmetrical reciprocity long expressed in interlocutory interaction" enables one to make sufficiently satisfactory sense of the data upstream of the western divide between the sacred and the profane.

Keywords: ancestor worship, senior citizens, intergenerational relations, religious respect.

Résumé : L'élaboration de l'évidence ethnographique typique du monde missionnaire et anthropologique d'antan en termes d'un culte des ancêtres et d'une forme de religiosité primitive pourrait n'être qu'un exemple de plus d'une lecture excessivement ethnocentrique d'un ensemble de phénomènes qui ne parlent en l'occurrence de manière plausible que de la reconnaissance cérémonieuse due à des "senior citizens » en tant que porteurs primordiaux de la survie collective typique des communautés rurales pré-modernes. En définissant la religion comme " une réciprocité obligatoire mais réciproque longtemps exprimée par des interactions interlocutrices " permet de se faire une idée des données de terrain en amont de la dichotomie occidentale entre le sacré et le profane.

Mots-clefs : culte des ancêtres, sentior citizens, rapports intergénérationaux, respect religieux. 
At 75, before becoming a still life, it is perhaps time, while still living ancestor, to say my last word on the so called (but badly so to my mind) "primitive worship of ancestral spirits". The issue has constituted a constant if not central concern of an anthropology I have made my own and which with hindsight I feel to have been just as liberating in intent as the theology of the same name (Singleton 2011a). Though they sought to sow therein the seeds of some sociological sense, my first publications about "ancestor worship" appeared in the field of (pastoral) theology (Singleton 1977b). A second series addressed itself, now in purely psycho-sociological terms, to geriatric issues (Singleton 2002b, 2003). Then having at last realized that the real is ance relational but asymmetric and that reciprocity takes place against an allological rather than an egological backdrop and that consequently recognition by others (Recherches Sociologiques 1992; MAUSS 2004) is more fundamental than self-identification, my latest and probably last contribution to the issue addressed itself to the intergenerational (Singleton 2008). These paradigm shifts involving changes in belief and behavior are the subject of this contribution.

While having made summary field trips to China and Vietnam and not being entirely ignorant of the literature ad hoc (Bontinck 1962; Jordan 1972; Wolf 1974; Smith 1974; Gasbarro 2009), it is with the typical African case that I am most familiar. The earliest expatriate observers of the African scene could not fail to notice that at a certain moment, their elderly household host, deposited a sliver of meat or poured out a drop of beer onto a potsherd placed within a miniaturized dwelling close to the compound's main hut, holding intercourse all the while with a seemingly invisible interlocutor. Though the relationship which manifestly met the eye amounted to no more than "speaking to the ancestors" (Singleton 2009b), most Europeans jumped to the conclusion that they had witnessed an act of Ancestor Worship, had ascertained a fact of Primitive Religion.

Accepting (dato non concesso) that this fact was one of fresh knowledge (rather than of an integral experience in which the notional element is but an analytical abstraction), the outside observer had found himself in a situation similar to that of radical translation described by Quine (1960): the reaching out from what you already know to what another knows but which is as yet unknown to you. The credibility of your conclusion - "the native knows X" - depends largely on the concrete continuity between $\mathrm{X}$ and the element in your knowledge on which you have chosen to align it. When, to borrow Quine's example, an interlocutor whose language you ignore, but who is clearly on the points of shooting what you call a rabbit, says gavegai it would be an excessive escalation were you to translate the word as "God".

My thesis here is that in representing dealings with the departed in terms of what their own culture took to be religious belief and behavior, western anthropologists started out on what Ricoeur (1975) would have called the wrong metaphorical foot. Let me immediately say which foot I consider would have been the right one. Some years ago, my elderly neighbor, a retired agricultural labourer, watched me struggle for hours trying to extract a recalcitrant concrete pole deeply embedded in clayey soil. He eventually hinted I should pour water into the hole. Despite feeling it would only make things worse, I do so - the pole came out like a knife from butter. My father-inlaw once saw me sweating over large screws: he suggested I dab the tips with oil the screws sank into the wood like knives in butter. I have come to realize that such experiences afford metaphorical material capable of making far more plausible sense 
of what was afoot and going forward in the phenomena which most western observers have instinctively interpreted as expressions of primitive religion.

\section{From data to facts}

Though neuro-physiologically they have to do with basically the same sensations and even perceptions as those I experience when seated at my table, a Pygmy or an Eskimo, arriving for the first time in the western "world" (taking the word in the sense of Merleau-Ponty's monde), would quite rightfully from their point of view conclude to a badly made hut or a weirdly constructed igloo. Likewise a Savoyard guide who had just lost his son on the slopes of Mont Blanc would henceforth have to do with quite another mountain than that of his more fortunate neighbor. Neither an artifact, such as a table, nor a natural object, such as a mountain, are of themselves possessed ab ovo of a universal and univocal signification. Hence, substantially the same material realities (be they cultural or natural) give rise to significant realizations which are not only specific to inculturated individuals but can proved irreducible and even incompatible the ones to the others. Far from being "already out there now for real", simply awaiting their complete and correct re-production in an observer's passively receptive mind, facts or facta are meanings to be "made up" (facere "to made") out of "givens" or data (dare "to give").

Between the data and the (factum) or "fact" of "ancestor worship" there yawns as I see it a credibility gap which need not have been crossed. The potential of the data (f) actualized as "ancestor worship" can rise to less ethnocentric thoughts. Believing is no seeing. Meanings are to be made and not discovered. In the last analysis, the solidity of the significations thus constructed (table, mountain, Waterloo or primitive religion) depends on criteria whose credibility answers to the causes and conventions certain actors of a particular culture at a given moment esteem worthwhile defending.

Take for instance the phenomenon of "spirit" possession. The elderly Dutch White Father who taught me Swahili and the even older Tanzanian priest of Inyonga parish to which the WaKonongo belonged, were both as equally aware as I was, of how the women possessed behaved: heaving and grunting, they fell convulsively to the ground eventually voicing the demands of their majini and mashetani (Singleton 1977a). However, though all three of us had basically to do with the same data what we made of them differed quite radically. For the skeptical Dutchman, there being, to his mind, no real fire, the smoke would dissipate as soon as psychotherapeutic treatment was available for the benighted savages in question. For the Tanzanian, still substantially steeped in the scholasticism of seminary training undergone in the 1930s, the very Fires of Hell burnt in Inyonga. For him the women implicated, rather than choosing to form a satanic sect headed by WaKamando, the wife of a former catechist, should have had recourse to an ecclesiastically approved exorcist. For my part, convinced there could be no smoke without a fire but also that the flames were psycho-sociologically produced, I took to participating actively in dealing with the spirits since they not only expressed situations of intergenerational and intersexual stress but contributed to their satisfactory solution. Amongst other things, the spirits with whom I dealt, restored the pecking order in a polygamous household, allowed an adolescent to refuse the aging fiancée her parents had willed upon her and enabled a young wife to winkle out a new dress from 
her reticent husband's savings. In not one of the many cases in which I was involved did I experience the need to invoke the existence of the Devil, of that metaphysical monster medieval theologians whose existence they believed could be read between the lines of the ethnographic materiel contained in the Bible - a reading contradicted by the irreducible complexity of the data in question (Schärf 1948). As WaKamando herself protested to me: "What I am doing has nothing to do with religion as you understand it but is merely a job like any other - Sio dini, ni kazi tu".

These three "(f)actualisations" of materially identical ethnographic evidence are not complementary, they are contradictory. Likewise substantially similar data bearing on the belief and behavior with regards the departed have given rise to the three contrasting "(f)actualisations" to be examined here.

\section{Ancestors as Saints and Holy Souls}

Even before the Reformation declared that fallen humanity could never of itself reach up to God, Christianity had long been in two minds as to the value of nonChristian faiths: was the soul "naturally Christian" as Tertullian suggested (anima naturaliter Cristiana) or had the Devil, as Justin the Martyr claimed, even gone so far as to create counterfeit simulacra of the sacraments? None the less, bent on adapting and inculturating the nonnegotiable supernatural hard core (depositum fidei) of divine Revelation, the more irenic and ecumenically minded amongst modern missiologists espied in certain elements of animistic manism, possible stepping stones towards the dogmatic tenets and liturgical practices of the True Faith. For instance, in worshipping their ancestors, non-Christians, it was thought, be they as highly civilized as the Chinese ${ }^{1}$ or as primitive as most Africans were deemed (if not doomed) to be, instinctively, albeit implicitly, witnessed to two supernaturally confirmed truths. Firstly, they articulated a desire for Eternal Life reserved for those who had proved themselves morally fit while on Earth, and, secondly, in imploring ancestral spirits to intercede with the High God, they had anticipated the intercessory role played by Saints (and especially the Virgin Mary) and even the Holy Souls in Purgatory².

To say the least, things theological and anthropological have radically changed even since the middle of the last century. On the one hand, at present no Christian believer in his right critical mind would adhere lock, stock and barrel, to the letter of the faith his Fathers held fifty years ago. On the other, few historians of religion and even less anthropologists now imagine that their data speak even latently of such traditional Judeo-Christian things as a Subsistent Being or an individually immortal

1 For the lucid refusal on the part Chinese intellectuals of what the West had then to offer in the way of religion and monotheism, $c f$. Gernet (1982) and for resistance to Christianity in general, $c f$. Pirotte 2004.

2 Books about the power of the dead in Purgatory and Heaven were still popular during the first half of the last century (at least twenty thousand copies were printed of the one written by the Archbishop of Cambrai (Chollet 1937) and in addition to catholic guilds intent on guaranteeing a Good Death to their members, there were even Archconfraternities disinterestedly dedicated to paying for masses intended to expedite the deliverance of souls abandoned ("délaissées") in the purifying fires of Purgatory of souls that of Our Lady of Montligeon boasted in 1902 that, in addition to the seven masses celebrated weekly for the deceased and the three monthly ones for forgotten sacerdotal souls, its members contributions had enabled 219,187 extra masses to be said for the departed (document in my possession). 
soul. Though in the sixties I had already been struck by the fortuitous convergence between the seemingly suicidal "Death of God Theology" and the remoteness of the so called African High God (Singleton 1972), this is not the place to dwell on the impact secular theology and political theology have had on the ideology and institutions of contemporary Christianity. More to our present point is an increasing awareness of the "anthropological" abyss opening up between the ethnographic evidence and missiological lucubrations.

In the first place, if the phenomenon under study was truly redolent of individual spiritual immortality, apart from the fact that this belief itself is far more classical than biblical, then there should logically have been a shrine for every departed person (male or female, young or old, native or stranger) and not, as was the case, for just a select few of elderly males. For, generally speaking, "shrines" were dedicated to the odd patriarch who, having been particularly difficult to manage in his dying days had, often on a diviner's recommendation, been returned home "ritually" from the nearby ancestral village. Having him thus once again conveniently and tangibly close to an appeasing hand enabled his descendants to avoid unwittingly treading on his cantankerous toes. What was thus brought back or came back of its own accord is a moot point and one which, even supposing those most concerned had given it much thought, can only be resolved in terms of the human logic prevailing locally. This latter (sometimes counting as many as nine component human parts) was never as dualistically simplistic as the body/soul, matter/spirit, time/eternity divide under which most expatriate minds labored.

In Africa, moreover, the Beyond was never the Above - the totally different and purely spiritual if not theocentric world, to which the disembodied soul of the western tradition departed with a sigh of relief. Neither Hades nor Heaven, the ancestral village to which departing Africans retired to carry on life more or less as usual, was often within walking distance of the one they had left behind. If myths mirrored a rather different world at the beginning, once the present had been stabilized, no African believed another quite other would one day take its place. Even if this one world was tiered, it was not torn between Time and Eternity. Whatever might have been the case before Paradise was lost, no collective and even less; sensual activities are programmed in that regained by the predestined few of Christian theology. In oral cultures, rather than to be passively seen forever, "gods" are made to be heard here and now, with an "ay!" for immediate action rather than an eye for speculation. The WaKonongo never wondered what their "spiritual" interlocutors looked like and even less what ontologically they might be in and for themselves; they only worried about what should be done in consequence of what they had been told. In the West, the Virgin Mary first and foremost puts in appearances and what she eventually says ("fast and pray") had already been heard on countless Sunday sermons; in Ukonongo, if the spokesperson seized by an Ancestral Spirit could be seen what counted was to heed an urgent injunction: "sacrifice a black hen or the drought will continue". The choice made by central figures, catholic or pagan, of marginal messengers (often nubile girls) can sociologically justified (Singleton 2009c).

Moreover, even if (dato non concesso) ancestors were sometimes said to act as intermediaries between God and the living (more often than not in answer to pointed questioning rather than as echoing spontaneously volunteered information), it was not 
because they were believed to be knelt contemplatively in His heavenly presence. To my knowledge nowhere in pre-Christian Africa was it question of saintly ancestors reaping eternal rewards in a divine Heaven or of being everlastingly punished in a diabolic Hell for failing to toe the moral line here below. As I see things too (but this vision is far from being idiosyncratic - (Singleton 2007; Babalao Olayibi 1993), there is even less question in ancestral Africa of a supreme symbol approximating to what nineteenth century missionaries called "God" - a being far more redolent of neoThomism and Tridentine catechetics than of the series of figures finally crystalizing in the biblical deity (Debray 2001). Whether it is philosophically plausible to speak thus a singular substance (a Divine Being naturally knowable independently of supernatural revelation) underlying the variegated array of ethnographic evidence is a moot point. Less debatable is the fact the earliest generation of explorers ${ }^{3}$, and missionaries in Africa were well aware that what they took to be native religious discourse fell far short of what they believed to be true faith in God and the Devil to be.

\section{Respect for religion or religious respect?}

My problem with the classical understanding of "ancestor worship" is not that anthropologists failed to put their finger on its sociological substance but that, despite their thick descriptions of the phenomenon, they continued to categorize and theorize it as religion. This was as much an epistemological error as a mistake in categorization. For even those who questioned current definitions of religion in the light of their field material rarely wondered what "defining" as such involved. And yet it is impossible to define what religion is without deciding what "what" itself is!

Understandings of the real have oscillated between the natural and the nominal. For the naturalist, in the last analysis, the really humanly real is what, substantially and significantly, remains after abstraction have been made of accidental appearances. In the same way as the supernaturalist sees the one true God and the one and only Devil behind the gods and demons of historical religions and ethnographic monographs, the naturalist speaks of Human Nature as essentially identifying human beings no matter what their age or sex, their color or their creed, their place in social space or historical time. This substantialism has spilled over into the realm of cultural realities. According to the naturalist, to live economically, to organize society politically, to marry and to worship are amongst the universal and univocal traits of an intrinsically immutable and essentially identical human nature. Cultural variations notwithstanding, such things as Marriage and Religion are thematic realities naturally recognizable not only in known human societies but in any group worthy of this essential and exclusive epithet (it being taken for granted that even the most superior of animals is intrinsically inferior to any specimen of humanity).

Nominalist anthropologists, on the other hand, have claimed 1. that if Human Rights can be defended without invoking the existence of a Human Nature this latter can be

3 In his journal, Cameron, exploring East and Central Africa, wrote (02.07.1874) that native "ideas of religion are nil or next to nil, they believe in spirits and to propitiate them make and wear their images and put offerings in little fetish huts. They also have a dim idea of a supreme Being but prayer or praise never entered into their thoughts" (Luwel 1976 137). 
erased thanks to Occam's razor (Singleton 2000); 2. That Marriage is not only an optical but an ontological illusion (Needham 1997: 107) at best a common denominator generalization applicable to a restricted number of peoples during a limited lapse of time - "any universal definition of marriage is vain" Leach 1961: 105; Needham 1997: 107); 3. That Religion, likewise, far from being an essential feature of human culture is a regional construct. "The methodical isolating out in the whole spectrum of human behavior a sector dubbed 'religious' has until recently been taken almost dogmatically for granted. Of late, however, the conviction that this approach reflected reality itself has increasingly come under fire (Nicolas 1993: 445)." As a renowned historian had already put it (Veyne 1971: 182 - alluding to Eliade and van der Leeuw): "It is with some cause for concern that one takes note of books entitled $A$ Treaty on the History of Religions or Religious Phenomenology - does this mean that some such thing as 'religion' exists? ... Different religions are simply aggregates of phenomena belonging to heterogeneous categories none of these amalgamations having the same composition as any another." For the nominalist singular names make sufficient sense, for the naturalist they are merely labels stuck on the surface of one substantial thing or theme.

I once made and spaced some shelves in keeping roughly with what I imagined to be small, medium and large size books. I would find ludicrous a suggestion that the shelves were more real and relevant than each and every tome and even more grotesque the affirmation that these latter were the accidental avatars, the ephemeral expression of some substantially archetypal Book. At the most (but to what avail?) in the light of some extremely residual or purely heuristic notion of materialized communication I could be persuaded that my books (and shelves) represented an intermediary stage between prehistoric rock engravings and the electronic devices likely to be implanted in the brains of future generations. Likewise, the nominalist is content with arranging individual things according to the causes and categories his culture deems presently defendable. The (super)naturalist, on the other hand, is intent on giving an absolutely (super)natural content to what he takes to be the fundamental facts of human culture as such. Hence, amongst other things, his radical rejection of gay marriage and his asserting that an atheist is not only implicitly religious but even an anonymous Christian.

To avoid this tentacular totalitarianism whereby religion grasping at everything ends up holding next to nothing, it is a well to fix socio-historic limits to what can, with some substantial significance, be properly defined as being religious. A graphic representation of the contrast between the naturalist and nominalist approach to religion might help: 
Fig.1
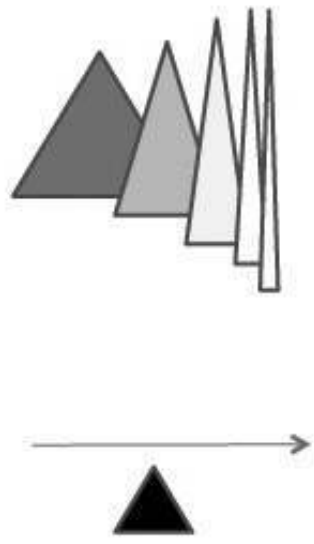

Fig. 2

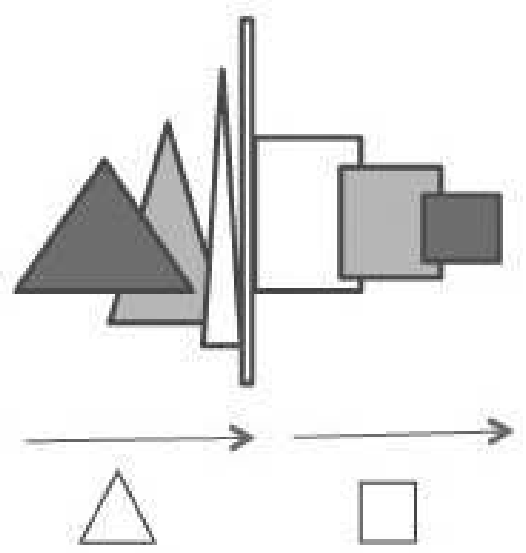

Both schemas represent an intercultural trip undertaken by an individual actor from his terminus a quo to a terminus ad quem embodied by the last in a series of cultures manifestly other. The fundamental issue is whether, as depicted in the first figure, the final "other" is essentially the same as the first (both and all intermediary cultures being supposedly variations on the substantial Sameness of transcultural themes) or whether, 
as in the second, they are singularly and irreducibly other (Otherness being here of the "essence").

Elsewhere (Singleton 2011b) I have invited the reader to accompany me on a far from fictitious trip (since I have lived and worked in most of the countries and cultures traversed) from my native England to my adopted Tanzania via Tunisia and Chad in the field of what at the outset the Western world designates as medical. En route I sought relief for a splitting headache from European doctors in France and Italy, from arabomuslim marabouts in the Maghreb and their counterparts in the Sahel and on the last leg from Bantu waganga.

The outcome of this safari depends on whether you see reality as artichoke or an onion. If you are convinced that whatever their cultures, men have been confronted with the same natural diseases, so as not to belittle them you will also conclude that they have come up with some at least minimally valid medical solutions. Medicine properly so called is represented by the first triangle on the left. It is heavily shaded because close (and increasingly so) to Reality itself (the black, underlying transcultural triangle - and transcendent where the Supernatural is concerned). Moving ever further to the right, through Chinese acupuncture and Hindu Ayurveda to African magic, medicines become increasingly ethnic until, in the end, medical elements are almost evanescent.

The second schema outlines an alternative to this ethnocentrically equivocal approach. Seeking to do full justice to the empirical evidence there comes a point where there is no longer any point in peeling away triangular traits since you have entered a series of worlds whose square configuration becomes clearly apparent on reaching the final destination and whose general features are represented by the underlying unsubstantial square. The absence of what you initially defined as medicine, disease and health being filled in this quite other world by the presence of something squarely different from your triangle, makes talk of ethno-medicine not only condescending but equal to ethnocide (Singleton 2006). Bio-medicine, presently prevailing in the tribal homeland of the West, is as ethnic as any other. The African mganga is in no way a primitive precursor of the scientifically trained doctor, since it his duty as much to make rain or rid you of an enemy as it is to hand you a leaf against your headache. Far from being empirically discovered, his materia medica would have been revealed by an ancestor and a headache not attributed to some neurophysiological disorder but to the ill will of a neighbor.

Exactly the same kind of trip can be made in the realm initially decreed to be religious. It is impossible to travel empty handed. The heavily shaded triangle on the left represents not only the baggage any traveler feels he requires but to which at first he has every right. Unless one is mad or masochistic or both, one rightly deems that the visions and values of one's present cultural location are if not absolutely absolute at least relatively so - which is not to exclude delocation. A convinced Christian can come to believe not only that the Koran is more triangularly religious that the Bible, but that triangular truths should be replaced fairly and squarely by post-religious rationality.

Leaving my English triangle in 1969 to live and work in Ukonongo, I could not immediately take leave of the modern suitcase with the compartments in which I had packed my Judeo-Christian and Greco-Latin baggage: God and the Pope, Heaven and Hell, the body and the soul, metaphysics and morals, the sacred and the profane, nature 
and culture... to mention but a few of the factors determining my understanding of the religious as representing Religion Itself (the Reference represented by the black triangle underlying the cultures of the first schema).

Already in France but especially in Italy, my rather Irish form of Roman Catholicism, tinged with the somewhat puritanical Protestantism of Victorian England, came in for its first intercultural shock: the survival of a strong pagan streak in Mediterranean Christianity (de Martino 1959). Passing through Islamic Tunisia, I realize that any transcultural definition of religion while perhaps still able to include a monotheistic streak will have to shed its trinitarian and incarnational features. After meeting some local marabouts in Chad I come to realize why Islamic purists in North Africa speak disparagingly of "Islam Noir" since in the Sahel genuine monotheism seems to have lost out to ancestral animism. On reaching my destination in Tanzania, the belief and behavior of the WaKonongo oblige me to modify and streamline still further my definition of religion if it is to retain any substantial semblance of universal and univocal relevance.

Having realized that my questions about the nature of spirits had never occurred to my interlocutors and that in politely replying to my preoccupations the possessed were creating from nothing a konongo metaphysic, I soon decided to rely on participant observation alone. I thus became convinced that left to themselves the WaKonongo showed, little or no interest in God or the Soul, nor did they ever spontaneously speculate about First Beginnings or Last Ends. If the WaKonongo had a religion is clearly was not centered on what religious beings might be but on what might be in it for us humans. Their "gods" seem to have been made for delivering the goods (in particular the rain - Singleton 2010) rather than for contemplative communion

To cut a long story short, it gradually dawned upon me that to all intents and purposes, the WaKonongo were as ignorant of and as indifferent to what I called "religion" as they were to what I understood by "medicine". More fundamentally, the WaKonongo made me realize that the distinction between Substantially the Same and its accidental appearances or cultural variations was if not an onto-epistemolgical mistake at least a peculiarly western dichotomy probably induced by the Indo-European linguistic distinction between nouns (embodying essences) and verbs (accessorily adding motion to the facts). When the WaKonongo had recourse to general terms such as ulozi or "sorcery" it was in no way to speak about the substance identifiable in particular instances but simply by way of a provisionally heuristic generation: "I am not yet able to put a name on the mlozi or sorcerer who has it in for me". They could speak about the wazimu in general but were far more concerned with the muzimu they could name. The root (which also figures in kuzimuni, the place where ancestors reside) is used to signify uzima - wrongly because restrictively translated as "health" when it meant well-being, wholesomeness (the sign of healthy muganga being not only his good health but his many wives and cattle).

Significantly (at least if you accept that words are not only things but are largely responsible for the things they talk about) there is no word in bantu languages for religion (the Swahili-Arabic term dini being now used) and no way of making the distinction fundamental in western religion between belief and knowledge. Such considerations coupled with the weight of the data collected, finally got the better of my preprogrammed presuppositions: rather than having little recognizably religious, at 
home in their square, the WaKonongo simply did not recognize my triangular religion. Consequently labeling their philosophy and practice of ageing according to our religious terms as "ancestor worship" is an intolerable form of ethnocentric imperialism.

Trying to make a universal sense of religion in terms of concrete content having proved ethnocentrically impossible, let me propose a heuristic understanding (first presented in Singleton 2003) based etymologically not on "making (substantial) sense" (legere) but simply on "being related" (ligare).

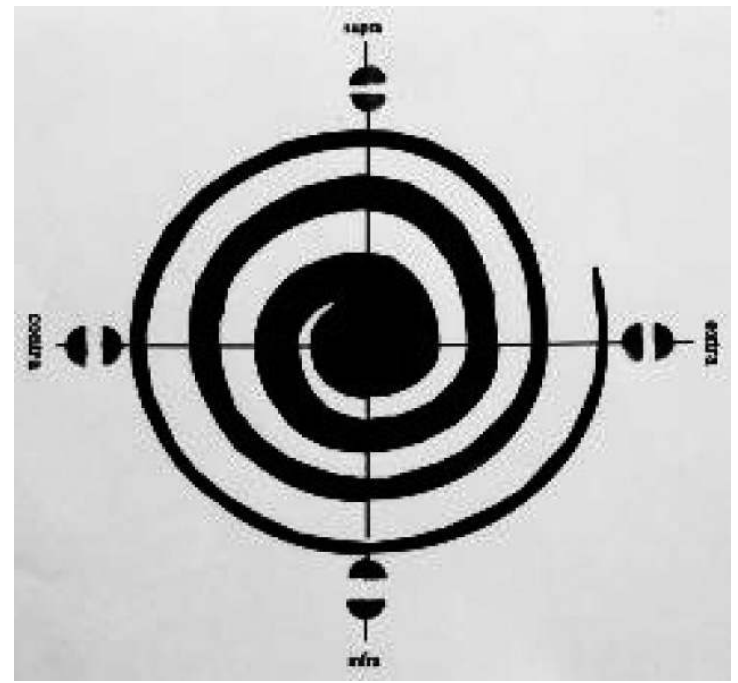

Though fundamentally one should start from the Other, I will begin with Ego at the center of the spiral but (as the continuous line purports) with the individual member of a whole, bound organically and ontologically to others and not with the solipsistic self which Descartes never managed to link with the body let alone society and which Rawls and other neoliberal ideologists have idealized as a monad whose contacts with others are purely contractual. Homo hierarchicus and not aequalis oblige, quantitatively and qualitatively the reciprocal but always asymmetrical relationships defining an individual's network (from close family to neighbors and beyond) diminish increasingly until their obligatory or religious character vanishes almost entirely...

1. on the right where one has to do with at the best a stranger and at the worst with an enemy who owing you nothing can take everything, your life included.

2. on the left where persons who in theory should be religiously your closest soul mates, in practice turn out to be your worst enemies - your mother who as a witch in Africa offers you as her entry fee to a coven, the colleague who in your department pays reverential respect for your budding ideas but rushes off to publish them under his own name.

On leaving the horizontal level of human relationships (taking "human" as defined by any given local anthropologic) one encounters the religiously vertical in the shape... 
3. below, of obligations to the para-human (rather than the non - or infra-human) the animal, vegetable and mineral world(s) of the western tradition but which in other more animistic traditions act as religious interlocutors - "animism" being defined as treating things as if they were persons and consequently as ends and not as means. In some cases, the religious spiral is inclusive of almost everything - Descola's Achuar spoke not only to plants but related pebbles to people and thus even more than the WaKonongo (Singleton 2001a) religiously ignored what the West identifies as nonreligious Nature. None the less, despite the almost all-inclusive nature of their cultures, many people feel that at this bottom level there could be an as yet a-religious Beyond... a feeling Drago shared staring out at the desert, and which modern philosophers have formalized as the noumenal (Kant), the Es gibt (Heidegger), the il y a (Levinas) and the Future (of techno-science and not only science fiction) which might lie in store for us: a salutary suspicion that the really Real is still to come if not forever beyond our religious reach (Singleton 2012).

4. above, obligations to supra-human interlocutors (some having become of less clearly human origin than others). In the first concentric layer figure the ancestors specific to given groups. When clan $\mathrm{A}$ is affected by more than average sickness and death, clans B and C will show sympathy, but it is up to the head of A to negotiate a satisfactory outcome with the (recently) departed, divined to be responsible. However, some issues (such as a lack of rain or game or the menace from marauders or a smallpox epidemic (Singleton 1976)) affecting far larger if somewhat loser groupings (a village, a "tribe"), solutions must be sought at the level of territorial spirits (Werbner 1977) or other such more global chargés d'affaires. Limdimi, the konongo Lord of the Forest (Animals) is a typical example of these "superior" partners, many, if not all of whom, could be associated with historical but exceptionally human figures such as Charlemagne or General Giap ${ }^{4}$.

If obligatory reciprocity is its fundamental criterion, then God does not belong to the ancestral religion of Africa. Unlike the God of conventional Christianity whom the believer can not only contemplate but enter into communion with on earth, the deus otiosus of ancestral Africa was aniconic and beyond religious reach: neither priest nor temple, the rare apotropaic sacrifice being destined to get him back to where he belonged and should never have left. When the WaKonongo attributed a death to "God" (mauti wa Mungu) far from making a blind act of submissive faith to the mysterious ways of divine Providence, they were simply saying that as no sorcerer or ancestor could be divined and blamed, the event was inexplicable. A less religious figure than the so but badly called "African High God" it would be difficult to imagine! There being at some point no religion and even a No! to religion as well as an Infinitely Other beyond even a Subsistent Being, would not appear an intolerable paradox to those (post)modern

4 In a mail (25.11.2012) my colleague and friend François Houtart noted that "ancestor worship was still very much alive and well in Vietnam both in catholic and communist circles - its meaning not being strictly religious unless in the sense you suggest of being tied up with a somewhat mythical past. Another phenomenon is that of the worship of heroes identified with divinities and possessed of village temples. It is thus that general Giap whom I knew and who is still alive has long had temples dedicated to him." In this present article, I have concentrated on lineage ancestors, having treated elsewhere of royal and territorial "spirits". 
theologians and philosophers who have welcomed the end of religion (Bonheoffer), proclaimed the Death of God (Kee) and opted for atheism (Levinas 1971).

\section{Ancestral anthropo-logic}

Why and how did it eventually dawn upon me that "ancestor worship" was a eurocentric misnomer for a basically pragmatic paradigm of belief and behavior? Simply because the WaKonongo told and taught me so. Perhaps because their woodland environment far from imposing a constant and cruel struggle for life proved prodigal even in difficult times, the WaKonongo, long before Nyerere's socialist slogan of selfreliance (kujtegemea), had managed to make ends meet to their satisfaction. Though they were as unaware of the fact as we are of the air we breathe, they firmly believed that no matter what the problem (shida) - be it repairing a bicycle, making it rain or resisting witches - someone, somewhere had the remedy (dawa or uganga - Singleton 1979)). They spoke about what few, to our minds exotic, rituals they indulged in as being all in a day's work (ni kazi tu). More fundamentally, however, the simple fact of working in the fields with them (Singleton 1975) as well as doing fieldwork amongst them, made me realize what was really at stake in the phenomena the West classes religiously as "ethno-medicine", "spirit possession" or "ancestor worship".

At first, however, I was somewhat put out by the fact that the local elders (apart from WaKamando, all male), occupied center stage and lorded it over all other actors as mere extras. Coming from a culture where the retired have taken to behaving retiringly, I was taken aback when even the more discrete among my elderly interlocutors automatically sat in the middle of the front row for collective photos and took it for granted that the best pieces of meat and the first calabashes of beer be theirs during meals or on festive occasions. Though most worked till their dying days, they were forever stopping to give peremptory advice even to adults and brooked no quibbling about the sententious decisions they delivered during neighborhood palavers. As grandfathers they doted on their grandchildren (at least while they were still toddlers), otherwise there was little love lost between contiguous generations - no doubt, as once was the case in Europe, because sons depended effectively (amongst other things for getting married) not only on the goodwill but the very goods of their fathers.

Initially, to explain why younger people and even elderly women put up with their pretentious posturing of senior citizens, I invoked such reasons as uncritical cultural inertia, the economic stranglehold exercised by elders or the simple fact that the over sixties constituting less than $5 \%$ of the demographic pyramid were far more supportable than the upper third of the pillar they represent in contemporary western society. Then it dawned upon me practically that in certain socio-historic situations, gerontocratic ideology and institutions could be synonymous with an aristocratic system, i.e. with, in given circumstances, the best way of speculating about and structuring survival be psycho-sociological or eco-economic. Widespread in Africa is the story about a young king who gets rid of all old people but who in dire straits is saved by the fact that one of his minister's has secretly kept alive and in store his ageing father. Throughout Africa too, in addition to tales about tricksters getting the better of the authorities, the elders themselves tell tales of young and even infant upstarts bent on upturning the status quo but who end by paying a heavy prize for the impertinence of their challenge. 
But it was the realities of everyday life which made me realize that in certain cultures, the older one grows so too increases one's public usefulness. Since my own existence amongst the WaKonongo depended physically and psychologically on this empirical evidence, it did not take me long to realize that materially, morally and metaphysically the elders had long been absolutely indispensable. They had come to know which soils yielded most and where game was likely to hide out; they had accumulated an ever deepening experience of the joys and pains of everyday life and had coped reasonably well not only with straight forward household and neighborly strife but with troubles caused by witches and spirits; and finally they were on the points of returning to the ancestral village and were thus well placed to negotiate a satisfactory deal with the rightful owners of the rain and the game and other such vital necessities.

In the eyes of all concerned, being grounded en experience, the respect paid by the rising generations to the outgoing one was justifiably in no way seen as usurped. It required no arbitrary means of policed enforcement. The mere threat of mystical sanctions (such as paternal malediction) was enough to make most actors toe the line the few who dared to cross it knowing they ran the risk not only of public opprobrium but punishment at the hands of leopard-men. Hence no one found anything untoward in the fact that the opinions and pronunciamento of living elders were almost unfailingly heeded or that (as had once been the case with the breadwinners of my youth) patriarchs were afforded the best food and drink. Had they been appraised of it, what would have surprised the WaKonongo would have been the opposition between what expatriates took to be the ceremonial deference shown to the aged and the purportedly religious worship of the departed. For they themselves only saw and spoke of a purely formal difference of degree and not of an onto-theological divide between politely presenting a calabash of beer to a living elder and ceremoniously pouring out a token drop of the same beer to the same person - now departed but also at least partly returned home.

There is no linguistic justification either for translating in our peculiarly religious terms what the WaKonongo and their likes said and did on the occasions described. From a purely phenomenological point of view it was a question of ceremony but not of ritual, of exchange but not of sacrifice, of negotiation but not of prayer, of interlocutors but not of spirits, of plenipotentiaries and not of intermediaries.

The inexistence of "ancestor worship" in some societies and its disappearance from others, confirms it underlying sociological nature. If, as Mary Douglas would have put it (1974), "ancestor worship" is absent from Pygmy bands and Hippy communes as is witchcraft, it is because this kind of culture lives in the present without any apodictic reference to an ancestral past and without any authoritative asymmetry between old and young, male and female and because should conflict rear its ugly head, those concerned can simply take their leave, going to live with another band or commune.

Human phenomena rise and fall in keeping not so much with "religious" speculation as with social structures. If "ancestor worship" is about religion it is in the relational sense we have given to the term and relations vary (and consequently religion) according to social shape and size. Hence, when intergenerational interests conflict rather than converge, "ancestor worship" having come adrift of its sociological anchorage, sociopathology can prevail until young and old manage to relate once again respectfully in an empirically justifiable fashion - as I was to during field trip to the Congo in 1986. In the same way that parish priests were wont to call upon the services of religious 
congregations to reactivate the flagging spirits of their flocks (crosses commemorating theses missions can still be seen in rural areas), African villagers too could invite teams specialized in cleansing communities of stultifying stress. These initiatives usually took the form of anti-witchcraft campaigns during which those (often the elders) deemed particularly responsible for the deteriorating climate were "encouraged" to confess their excessive demands and to destroy the objects materializing them (Singleton 2009a). Conviviality thus restored, in pre-colonial times the local community was able to continue business as usual. However, with the advent of colonial times, the fittest on whom social survival depended were no longer entirely and evidently the elders. Know-how (together with the power, the prestige and the profits it entailed) became at least partly and often rapidly the prerogative of the rising generation. In the West, the unintended and unwanted side effects of this socio-economically induced shift in the balance of power between generations were mitigated by such factors as suprafamilial social security (both for young and old) and by the elderly being enabled at once to re-identify themselves as a group ("Grey Panthers"!) and to reinvent a relevant intergenerational role.

Unfortunately the absence of such safety valves in the Congolese villages I studied in (Singleton 1986) had led to social pressure building up to exploding point. From being a factor of integration "ancestor worship" had degenerated into the most disintegrating form of witchcraft. On the one hand, failing to realize that power now depended as much if not more on mastering the unknown future than on repeating the established past, the elders continued to claim the respect and rewards which had until recently been rightfully theirs. On the other, to escape being devoured (materially or mystically) by their village elders, those young people who could, fled to safer urban havens, abandoning en route the ritual trappings of an ancestor worship which had forfeited its sociological raison d'être. Unfortunately too, failing to realize the underlying causes responsible for this hardening of the social categories by the elders (such as the absence of private or public pensions, palliative care, unemployment benefits) some analysts and activists spoke rather glibly of "social pathology" and somewhat one-sidedly promoted the rights of youth (Cambron 2007).

\section{From symbol to sacrament}

I am, of course, not the first anthropologist to imply that "ancestor worship" is simply a symbolization of seniority, leaving the burden to prove more on the shoulders of those seeking something more religious. However, given the tendency for a symbol to be taken as a somewhat superficial sign for something deeply significant in itself, I prefer to speak of the ceremonious respect for senior citizens once a key factor in the survival of village life in Africa, as a genuine sacrament. For it was at once expressive of but also by that very fact effective (ex opere operato) of the intergenerational language and logic appropriate to and appropriated by the milieu typical of ancestral Africa. Times have changed. Sociohistorically speaking it is unrealistic to dream of a literal return to the traditionally justified forms respect. On the other hand, sociologically speaking it would be anarchically unrealistic to aim at dispensing with all formalities: a completely symmetrical equality between the generations would be an atopian nightmare and not a utopian dream. As of now, supposing that the ceremonious to be 
credible requires continuity with concrete conditions, a fresh sacramentalization of the emerging intergenerational relations or religion is called for. Speaking as one of them: Long life to senior citizens!

\section{References}

Babalola OlabiYi, Yai, 1993. "From Vodun to Mawu: Monotheism and History in the Fon Cultural Area", in Jean-Pierre Chrétien (ed.). L'invention religieuse en Afrique noire. Paris: Karthala.

Bontinck, Franz, 1962. La lutte autour de la liturgie chinoise au $17^{\text {ème }}$ et $18^{\text {ème }}$ siècles. Paris-Louvain : Nauwelaerts.

Cambron, Elie and Daniel Delabie, 2007. Où veulent-ils en venir ? Cheminements de communautés interclaniques en milieu coutumier. Idiofa (RDC) : Editions Kimvuka ya Lutondo.

Chollet, Msg, 1937. Nos morts. Ceux du foyer. Au Purgatoire et au Ciel. Paris : Lethielleux.

Chrétien, Jean-Pierre (ed.), 1993. L'invention religieuse en Afrique. Histoire et religion en Afrique noire. Paris: Karthala.

Debray, Régis, 2001. Dieu, un itinéraire. Matériaux pour l'histoire de l'Eternel en Occident. Paris : Odile Jacob.

De Martino, Ernesto, 1959. Sud e Magia. Milano: Feltrinelli.

Douglas, Mary, 1974. Natural Symbols. London: Penguin.

Gasbarro, Nicola, 2009a. Le Lingue dei Missionari. Roma: Bulzoni (several contributions on early Christian missionaries in China).

-, 2009b. Le Culture dei Missionari. Roma: Bulzoni (several contributions on early Christian missionaries in China).

Gernet, Jean, 1982. Chine et Christianisme. Paris: Gallimard.

Jordan, David K., 1972. God, Ghosts and Ancestors. Folk Religion in a Taiwanese Village. Berkeley: California University Press.

LEACH, Edmund, 1961. Rethinking Anthropology. London: Athlone Press.

Levinas, Emanuel, 1971. Totalité et infini. Essai sur l'extériorité. Paris: Martinus Nijhoff.

Luwel, Marcel, 1976. "Verney Lovett Cameron ou l'echec d'un concurrent de Stanley”, La Conférence de Géographie de 1876, pp. 57-169. Bruxelles: Académie des Sciences d'Outre-mer,

MAUSS, 2004, 23, "De la reconnaissance. Don, identité et estime de soi".

NeEDHam, Rodney (ed.), 1977. La parenté en question. Onze contributions à la théorie anthropologique. Paris: Seuil.

Nicolas, Gilles, 1993. “La réduction 'religieuse' des visions traditionnelles du monde et ses effets politiques contemporains: le cas du Nigeria”, in Jean-Pierre Chrétien (ed.). L'invention religieuse en Afrique noire. Paris: Karthala.

Pirotte, Jean (ed.), 2004. Résistances à l'évangélisation. Paris: Karthala.

Recherches Sociologiques, 1992 (2), "Souffrances sociales et attentes de reconnaissance".

Quine, Willard van Orman, 1960. Word and Object. Cambridge: MIT Press.

Riceur, Paul, 1975. La métaphore vive. Paris: Seuil.

SchÄrF, Rirokah, 1948. "Die Gestalt des Satans in Alten Testament”, in C. G. Jung, Symbolik des Geistes, pp. 153-319. Zürich: Rascher Verlag. 
Singleton, Michael, 1972. "Theology, 'Zande Theology' and Secular Theology”, in Essays presented to Sir Edward Evans-Pritchard, pp. 130-157. Oxford: Blackwell.

-, 1975. "Prêtre Ouvrier-Prêtre Ujamaa", Spiritus, 61, pp. 427-436.

-, 1976. "Smallpox in Person", Anthropos, 71, pp. 169-179.

-, 1977a. “Obsession with Possession”, Pro Mundi Vita, African Dossier, July, pp. 1-35.

-, 1977b. "Ancestors, Adolescents and the Absolute", Pro Mundi Vita, September, pp. 1-355.

-, 1979. "Dawa: Beyond Science and Superstition”, Anthropos, 74, pp. 817-863.

-, 1986. "Une recherché en éco-santé au Zaïre”, Prelude, (Namur), 1, pp. 36-46.

-, 1990. "Which Christians? What Witches? From a Survey in South-West Nigeria", Psychopathologie africaine, 23 (1), pp. 61-76.

-, 2000. "De la déclaration définitive à la discussion décisive des Droits de l'Homme", Annales d'Études Européennes, 1, pp. 47-67.

-, 2001a. "Un anthropologue entre la Nature de la Culture et la Culture de la Nature" in Fréderic Debuyst et al. (eds), Savoirs et jeux d'acteurs pour des développements durables, pp. 81-111. Louvain la Neuve: Bruylant Academia.

-, 2001b. "De l'épaississement empirique à l'interpellation interprétative en passant par l'ampliation analogique", Recherches Sociologiques, 1, pp. 15-40.

-, 2002a. "Du culte des ancêtres à la rentabilité des seniors: pour une anthropologie réaliste des (r)apports du troisième âge", in François Gendreau et al. (eds), Jeunesses, vieillesses, démographies et sociétés, pp. 61-81. Louvain la Neuve-Paris: Academia-1'Harmattan.

-, 2002b. "Devenir vieux - ailleurs et autrement", in Vivre et 'Soigner' la vieillesse dans le Monde, actes du colloque international, Gênes, Mars, DISA/Università dei Studi di Genova, - text revised and augmented in Documents du travail du SPED, 16, 2003, pp. 1-57.

-, 2006. “L'ethnomédecine est-elle ethnocidaire?", in Laurent Pordié (ed.), Panser le monde, penser les Médecines, pp. 53-68. Paris: Karthala.

-, 2007. "Le pillage identitaire de l'Afrique ancestrale" in P. Ngandu Nkashama (ed.), Itinéraires et trajectoires: du discours littéraire à l'anthropologie. Mélanges offerts à Clémentine Fayik-Nzuji Madiya, pp. 263-283. Paris: L'Harmattan,.

-, 2008. “La carte d'identité senior - à renouveler?” in Solidarité Intergénérationnelle, pp. 295-314. Lisboa: Universidade Aberta.

-, 2009a. "Le Mal africain - pas si mal que ça!”, Recherches Sociologiques, 1, pp. 149-161.

-, 2009b. "Speaking to the Ancestors: Religion as Interlocutory Interaction", Anthropos, 104, pp. 311-332.

-, 2009c. "En marge monumental" in M. Daveluy et L.-J. Dorais (eds), À la périphérie du centre. Les limites de l'hégémonie en anthropologie, pp. 11-24. Montréal: Liber.

-, 2010. Histoires d'eaux africaines. Louvain la Neuve: Academia.

-, 2011a. "Pour une anthropologie de la libération", Recherches Sociologiques, 42 (1), pp. 45-61.

-, 2011b. "Parcours ethniques, implications éthiques" in Investigations d'anthropologie Prospective. Implications et explorations éthiques en anthropologie, pp. 15-44. Louvain: Academia.

-, 2012. L'uomo che (non) verrà. Udine: Editrice Universitaria Udinese.

Sмітн, Robert J, 1974. Ancestor Worship in Contemporary Japan. Stanford: Stanford University Press.

5 Pro Mundi Vita publications were translated into French, German, Dutch and Spanish. 
Michaël-Singleton

Veyne, Paul, 1978. Comment on écrit l'histoire. Paris: Seuil.

Wolf, Arthur P., 1974. Religion and Ritual in Chinese Society. Stanford: Stanford University Press. 